\title{
ISOLATION OF Fonsecaea pedrosoi FROM THORNS OF Mimosa pudica, A PROBABLE NATURAL SOURCE OF CHROMOBLASTOMYCOSIS
}

\author{
Claudio Guedes SAlgAdo(1,2), Jorge Pereira da SILVA(1,3), José Antônio Picanço DINIZ(4), Moisés Batista da SILVA(1), Patrícia Fagundes da COSTA(1),
} Claudio TEIXEIRA(4) \& Ubirajara Imbiriba SALGADO(1)

\begin{abstract}
SUMMARY
We report the isolation of Fonsecaea pedrosoi from thorns of the plant Mimosa pudica L. at the place of infection identified by one of our patients. Clinical diagnosis of chromoblastomycosis was established by direct microscopic examination and cultures from the patient's lesion. The same species was isolated from the patient and from the plant. Scanning electron microscopy of the surface of the thorns showed the characteristic conidial arrangement of $F$. pedrosoi. These data indicate that $M$. pudica could be a natural source of infection for the fungus $F$. pedrosoi.
\end{abstract}

KEYWORDS: Chromoblastomycosis; Fonsecaea pedrosoi; Mimosa pudica; Thorns.

\section{INTRODUCTION}

Chromoblastomycosis is a subcutaneous mycosis with a cosmopolitan distribution. It has been reported from North, Central, and South America, Europe, Asia, Australia, Oceania, and Africa, and is characterized by verrucous-nodular lesions on the skin caused mainly by the fungus Fonsecaea pedrosoi ${ }^{8,9}$. The infection begins with the inoculation of the fungi, which spread to the surrounding skin area through the lymphatic vessels or disseminate widely through a hematogenous action ${ }^{1}$. Although Cladophialophora carrionii isolation from cacti in the chromoblastomycosis semi-arid endemic zone in Venezuela has been reported ${ }^{6,16}, F$. pedrosoi isolation from different samples such as rotten trunks and plant debris has been shown ${ }^{7}$, and a study in the state of Maranhão (Northeast Brazil) has suggested a relation between the occurrence of lesions on the buttocks and the habit of sitting on babaçu (Orbignya phalerata) shells ${ }^{14}$, there is no clear demonstration of the correlation between the natural source and patient infection for $F$. pedrosoi, the main agent for chromoblastomycosis in Brazil.

Recently, SILVA et al. demonstrated that Pará State has a high prevalence of chromoblastomycosis, registering more than 300 cases in the last 40 years $^{15}$. In the last two years, more than 45 new cases were diagnosed in our Institution. Most of the patients describe the first sign of the disease as a small papule arising after a traumatic skin puncture received near their house or during excursions into the forest. One of these patients identified the exact geographical place where she was injured. We demonstrate that $F$. pedrosoi can be cultivated from thorns of the tropical plant Mimosa pudica, found at the place of the injury, what indicates that $M$. pudica could be a natural source for the chromoblastomycosis agent $F$. pedrosoi, which would infect the host through percutaneous inoculation.

\section{MATERIAL AND METHODS}

Patient, plant and location: A 32-year-old woman came to our service with complaints of a skin lesion which appeared two to three months after a fall over some plants at the margin of a dirt road near her house. She related to us that after the fall, a thorn from the plant known as "maria-fecha-a-porta" penetrated her skin and it was impossible for her to remove it, what originated the lesion. The site is on a branch from the main road to the city of Bonito, located $160 \mathrm{~km}$ away from Belém, the capital of Pará, Northeast Amazon, Brazil. Several excursions to that area were organized in order to obtain specimens for the analysis.

Specimen field collection: To confirm the hypothesis of infection from $M$. pudica at that site, three thorns from each of two $M$. pudica plants were collected. Specimens were kept isolated from each other and from the environment inside Descartex boxes (Becton-Dickinson, Paraná, Brazil) used only for this purpose. At the lab, boxes were opened inside the biological safe cabinet class IIA and thorns were removed and cultured, therefore avoiding exogenous contamination. After confirming the presence of $F$. pedrosoi, it was attempted to isolate the fungi from $M$. pudica located at three other sites. The first was on the same road. Since the small village is located $10 \mathrm{~km}$ away from the site of infection, thorns of two plants at every $2 \mathrm{~km}$ interval for $10 \mathrm{~km}$ either side of the village were collected. Three thorns from each plant were cultured. The second site was a dirt road and the third an open area at the backyard of the laboratory, both in the city of Marituba, where we also found M. pudica.

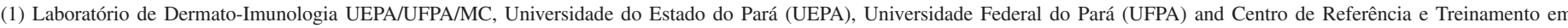
Dermatologia Sanitária do Estado do Pará "Dr. Marcello Candia” (MC), Marituba, Pará, Brasil.

(2) Departamento de Patologia, UFPA

(3) Departamento de Farmácia, UFPA

(4) Unidade de Microscopia Eletrônica, Instituto Evandro Chagas, Belém, Pará, Brasil.

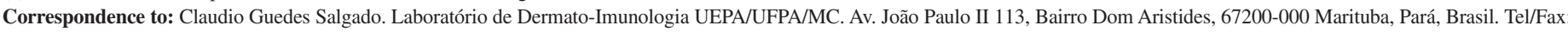
(55)(91)256-9097. E-mail: csalgado@ufpa.br 


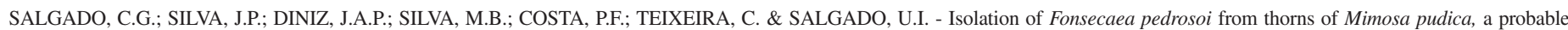
natural source of chromoblastomycosis. Rev. Inst. Med. trop. S. Paulo, 46(1):33-36, 2004.

Direct microscopic examination: Samples from the patient's lesion and from the thorns were collected for direct microscopic examination. Scrapings were collected from the surface of the lesion and of the thorns with a surgical blade No. 15. A drop of $10 \% \mathrm{KOH}$ was applied to the specimens on glass slides, covered with cover glasses and analyzed under optical microscope after 20 minutes for human tissue and after a minimum of 40 minutes for thorns.

Culture: Part of the specimens obtained for direct microscope examination were used for culture in the Sabouraud agar medium with cyclohexamide and chloramphenicol (Mycosel, Becton Dickinson, USA) in $15 \mathrm{x}$ $2 \mathrm{~cm}$ Petri dishes. The thorns were cut at their base and cultured either by puncturing the medium with the thorns, or leaving them directly on it. The black fungi were prepared for microculture on small blocks of potatoglucose-agar as previously described ${ }^{12}$.

\section{Scanning Electron Microscopy (SEM):} To detect the presence of $F$. pedrosoi growing directly on the thorns, they were embedded in Mycosel (Becton Dickinson, USA) and put in small round cover-glasses layered with poly L-lysine D (Sigma, USA) inside glass Petri dishes in a moist atmosphere where water was constantly added. On the 14th day in culture thorns were fixed by immersion in $1 \%$ osmium tetroxide (Sigma, USA) and 25\% acetone for three hours at RT, followed by dehydration in 50, 70, 90 and $100 \%$ acetone for 20 minutes at each step. Finally, specimens were dried by the critical point method with the Emitech K850 (Emitech, England), mounted on stubs with carbon tape, metalized with a thin layer of $\cong 20 \mathrm{~nm}$ of gold using Emitech K550 sputtering device (Emitech, England) and observed with the LEO 1450VP scanning electron microscope (LEO, England).

\section{RESULTS}

The patient came for medical consultation on May 9, 2002, presenting a well-delimitated vegetant-exsudative plaque of $3 \times 2 \mathrm{~cm}$ on the right knee (Fig. 1A), with an evolution period of six months. Chromoblastomycosis was confirmed by direct examination, presenting the pathognomonic brownish, round, thick-walled, sclerotic bodies with crosswalls (Fig. 1B).

Analysis of the geographical site identified

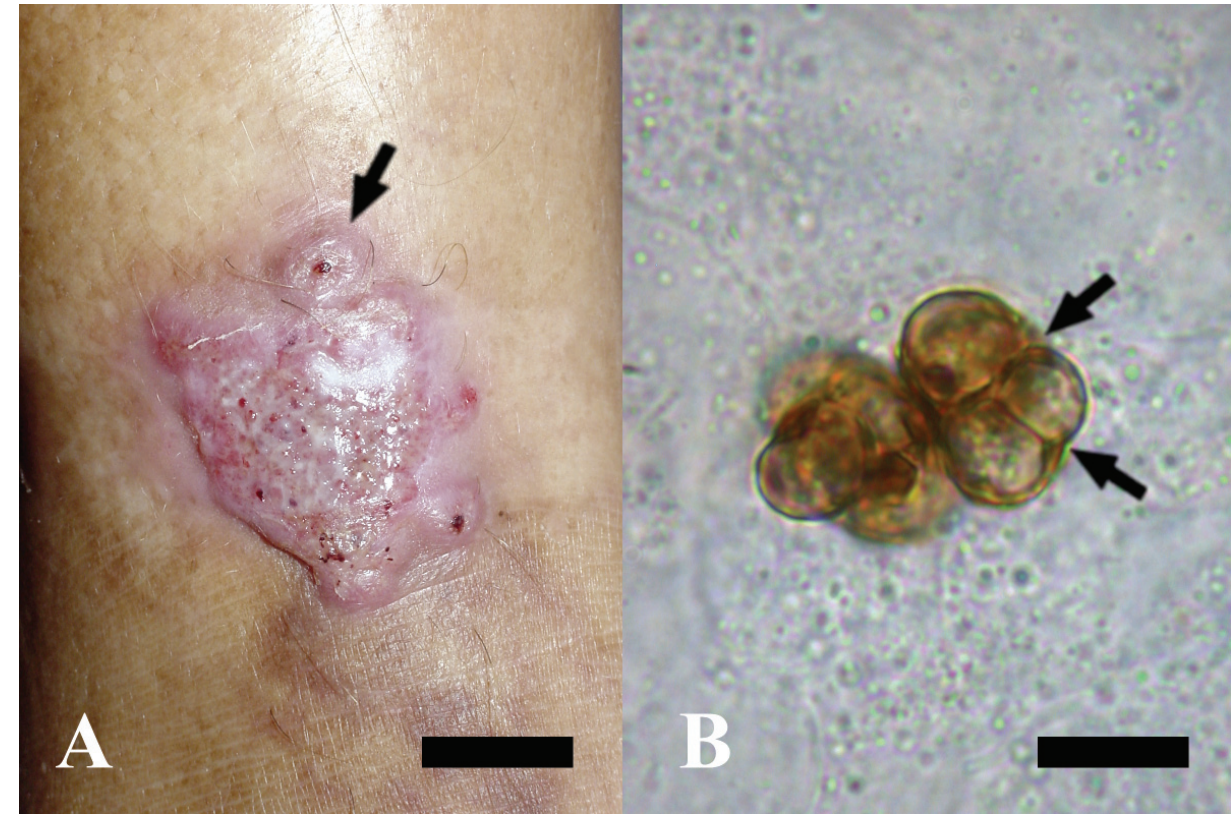

Fig.1 - Patient lesion and microscopic direct examination. The $3 \times 2 \mathrm{~cm}$ verrucous-exsudative plaque on the right knee of the patient developed from the superior left part of the lesion (A, arrow), two months after a traumatic puncture with a thorn from the plant $M$. pudica. Direct examination demonstrated the presence of darkly pigmented sclerotic bodies with crosswalls (B, arrows). Scale bars: A: $2 \mathrm{~cm}, \mathrm{~B}: 15 \mu \mathrm{m}$.

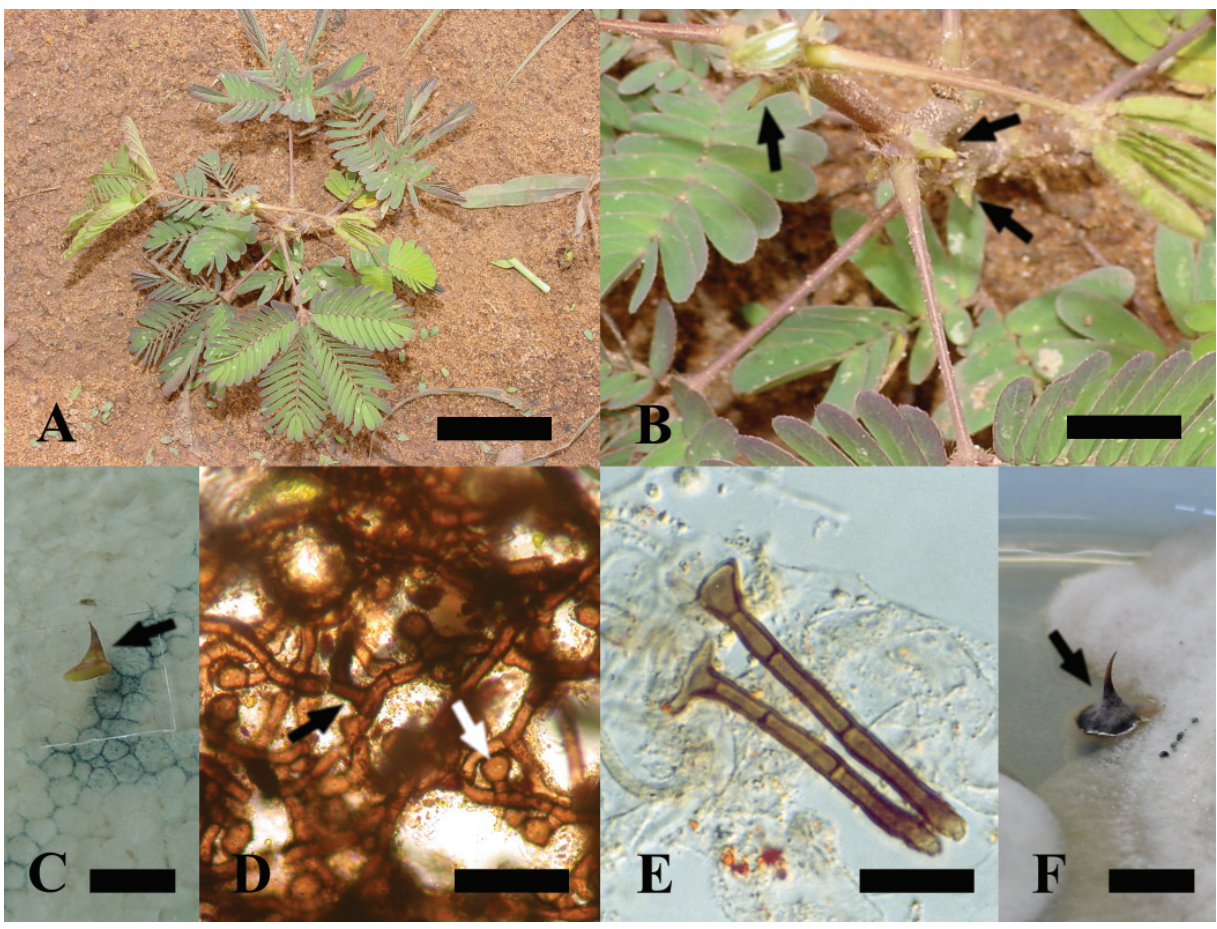

Fig. 2 - The plant, its thorns, microscopic direct examination and culture. M. pudica (A) is known as a "sensitive plant" because it closes its leaves after being touched. It has an erect and branching stem heavily filled with thorns (B, arrows). The thorns were cut at their base and scraped for direct examination $(\mathrm{C}$, arrow), where two types of dematiaceous hyphae were observed: sinuous, long, branched, septated hyphae (D, black arrow) with a globous terminal portion (D, white arrow) or small ( 3 to 4 cells) hyphae with a blunt-end in one extremity and a cup-shaped-end on the other extremity (E). In culture, after 14 days at room temperature, colonies of black filamentous fungi with a rough surface could be identified on the thorn (F, arrow). Scale bars: A: $6 \mathrm{~cm}, \mathrm{~B}: 2 \mathrm{~cm}, \mathrm{C}$ and F: $1 \mathrm{~cm}, \mathrm{D}: 50 \mu \mathrm{m}, \mathrm{E}: 30 \mu \mathrm{m}$. 
by the patient as the contamination area demonstrated the presence of plants that are very common in tropical and subtropical regions, such as Mimosa pudica L. (Fig. 2A and B), a perennial plant with an erect and branching stem heavily filled with thorns, with red to pink flowers, an average height of $0.5 \mathrm{~m}$ and high nitrogen-fixing ability. The species which was identified based on the classification key described by BARNEBY (1991) - is known as sensitive plant in English spoken countries; sensitive in French possessions or former colonies; dormidera, ciérrate puta (cierra tus puertas), sensitiva, dormilona, vergonzosa and tem vergüenza in Spanish Latin America; pinahuihuixtle and quecupatli in Mexico; honte in Haiti and; dormideira and maria-fecha-a-porta in Brazil ${ }^{2}$.

Smears from scraps of thorns revealed the presence of dematiaceous hyphae in close contact with plant cuticle (Fig. 2C, D, E and F). Cultures of both specimens obtained from patient's lesion and from thorns obtained at the site of infection, grew colonies of black filamentous fungi, with a velvet surface and dark green or gray color after two weeks at room temperature (Fig. 3A and B).

Cylindrical, intercalary or terminal conidiophores, loosely branched, originating $3.0 \times 1.5 \mu \mathrm{m}$ subhyaline conidia, arranged in short chains, characteristic of F. pedrosoi ${ }^{4,5}$ were observed (Fig. 3C and D).

SEM was performed to detect growth of $F$. pedrosoi on the surface of thorns. After 14 days in culture, ultrastructural analysis showed characteristic Cladosporium pattern, with cylindrical conidiophores originating $3.0 \times 1.5 \mu \mathrm{m}$ oval shape conidia, arranged in short chains growing on the surface of the thorns (Fig. 4).

\section{DISCUSSION}

It is well known that fungi and other microorganisms as bacteria and viruses can infect plants or even live in a saprobic or parasitic fashion $^{10}$, but there has been no clear demonstration of the growth of $F$. pedrosoi directly on plant, as we show here. Previous works have demonstrated that it is relatively easy to isolate dematiaceous fungi, such as $F$. pedrosoi or $C$. carrioni, from different natural sources, including decomposing material found in soil ${ }^{7}$. All plants analyzed in the present work were alive at the time specimens were obtained and put inside Descartex boxes to avoid exogenous contamination. The presence of dematiaceous hyphae in close contact with $M$. pudica cuticle suggests a real interaction between $F$. pedrosoi and $M$. pudica, diminishing the chances of contamination from propagules which could be arrested from soil and found at the surface of the thorns by chance.

Although we were able to isolate $F$. pedrosoi from thorns of $M$. pudica at the site of infection of a patient, on the other two locations explored it was impossible to isolate fungi from thorns. A possible explanation for this would be the existence of "reservareas" of $F$. pedrosoi - a term

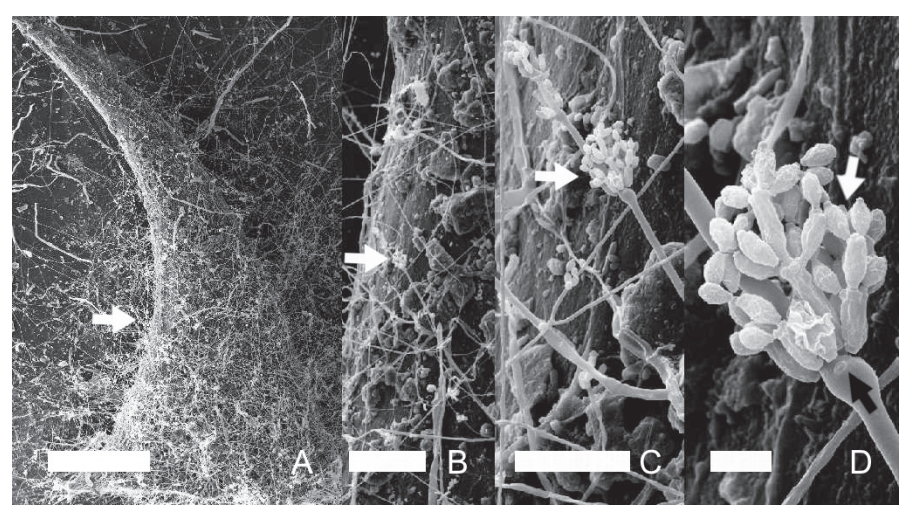

Fig. 4 - Analysis by SEM clearly identifies the microculture pattern of $F$. pedrosoi on the surface of the thorn. Fig. 4A shows one of the thorns visualized entirely by SEM after culture. The arrows on A, B and C identify the place of one of the groups of conidiogenous cells and their conidia on the surface of the thorn. On D, the white arrow shows the characteristic cladosporium pattern with cylindrical phialides originating small conidia, arranged in short chains which is compatible with the chromoblastomycosis fungi F. pedrosoi. Note one of the scars (black arrow) from where the conidiophores originate. Scale bars: A: $310 \mu \mathrm{m}, \mathrm{B}: 60 \mu \mathrm{m}$, C: $19 \mu \mathrm{m}, \mathrm{D}: 3 \mu \mathrm{m}$.

generally used to define a special area where infectious forms of paracoccidioidomycosis are found ${ }^{11}$ - in the city of Bonito. We are now examining other regions where chromoblastomycosis patients attending our Institution reside, in order to find and trace the possible "reservareas" of $F$. pedrosoi in the state of Pará.

It is also reasonable to think that $F$. pedrosoi could be found in the 


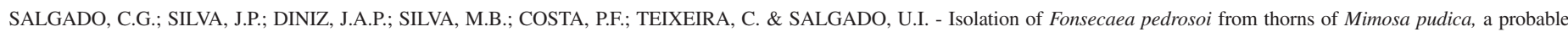
natural source of chromoblastomycosis. Rev. Inst. Med. trop. S. Paulo, 46(1):33-36, 2004.

surface of other plants at the "reservarea" or even on the soil, but other studies are necessary to elucidate this and the interaction between the fungus and the plant.

The majority of chromoblastomycosis cases we have seen shows lesions on the legs, which are consistent with previous reports ${ }^{3}$ and can be correlated with the height of the plant. The type of location we studied is common in the North of Pará and we have had the opportunity to detect the same type of plant along dirt roads. They are located at the limit of the road and the forest, facilitating human contact with thorns.

Our findings suggest there is a plant-human transmission of fungi causing chromoblastomycosis, what would confirm previous observations of evidence for percutaneous inoculation of $F$. pedrosoi ${ }^{13}$. The knowledge that a common plant, usually found along the edges of dirt-roads, would be capable of maintaining infectious forms of $F$. pedrosoi might be significant for the prevention of this disease.

\section{RESUMO}

Isolamento de Fonsecaea pedrosoi a partir de espinhos da planta Mimosa pudica, uma provável fonte natural de cromoblastomicose

Este trabalho demonstra o isolamento de Fonsecaea pedrosoi de espinhos da planta Mimosa pudica L., a partir do local de suposta infecção identificado pela paciente infectada. O diagnóstico clínico de cromoblastomicose foi estabelecido pelo achado de corpos fumagóides no exame microscópico direto e pelas culturas de F. pedrosoi do material obtido da lesão da paciente. A mesma espécie foi isolada da paciente e da planta. A microscopia eletrônica de transmissão da superfície dos espinhos evidenciou a disposição conidial característica de F. pedrosoi. Estes dados indicam que a planta $M$. pudica deve ser uma fonte natural de infecção do fungo $F$. pedrosoi.

\section{ACKNOWLEDGMENTS}

The authors are very grateful to Professors Rubem David Azulay, Clarisse Zaitz, Wanderley de Souza, Bodo Wanke and Josep Guarro for reviewing the manuscript. This work was supported by Fundo de Ciência e Tecnologia do Estado do Pará (FUNTEC), by Programa de apoio à Pesquisa da Universidade do Estado do Pará, by PROINT, Universidade Federal do Pará, by Secretaria Executiva de Saúde Pública do Estado do Pará (SESPA) and by Fundação Nacional de Saúde (FUNASA).

\section{REFERENCES}

1. AZULAY, R.D. \& SERRUYA, J. - Hematogenous dissemination in chromoblastomycosis. Report of a generalized case. Arch. Derm., 95: 57-60, 1967.
2. BARNEBY, R.C. - Sensitivae censitae: a description of the genus Mimosa Linnaeus (Mimosaceae) in the New World. New York, Botanical Garden, 1991.

3. BURKS, J.B.; WAKABONGO, M. \& McGINNIS, M.R. - Chromoblastomycosis. A fungal infection primarily observed in the lower extremity. J. Amer. podiatr. med. Ass., 85: 260-264, 1995.

4. CARRION, A.L. \& SILVA-HUTNER, M. - Taxonomic criteria for the fungi of chromoblastomycosis with reference to Fonsecaea pedrosoi. Int. J. Derm., 10: 3543, 1971.

5. DE HOOG, G.S.; GUARRO, J.; GENÉ, J. \& FIGUERAS, M.J. - Atlas of clinical fungi. Utrech and Reus, Centraalbureau voor Schimmelcultures and University Rovira i Virgili, 2000.

6. DE HOOG, G.S.; QUEIROZ-TELLES, F.; HAASE, G. et al. - Black fungi: clinical and pathogenic approaches. Med. Mycol., 38 (suppl. 1): 243-250, 2000.

7. GEZUELE, E.; MACKINNON, J.E. \& CONTI-DIAZ, I.A. - The frequent isolation of Phialophora verrucosa and Phialophora pedrosoi from natural sources. Sabouraudia, 10: 266-273, 1972.

8. LACAZ, C.S.; PORTO, E. \& MARTINS, J.E.C. - Micologia médica: fungos, actinomicetos e algas de interesse médico. São Paulo, Sarvier, 1991.

9. McGINNIS, M.R. - Chromoblastomycosis and phaeohyphomycosis: new concepts, diagnosis, and mycology. J. Amer. Acad. Derm., 8: 1-16, 1983.

10. OMACINI, M.; CHANETON, E.J.; GHERSA, C.M. \& MULLER, C.B. - Symbiotic fungal endophytes control insect host-parasite interaction webs. Nature (Lond.), 409: 78-81, 2001.

11. RESTREPO, A.; McEWEN, J.G. \& CASTANEDA, E. - The habitat of Paracoccidioides brasiliensis: how far from solving the riddle? Med. Mycol., 39: 233-241, 2001.

12. RIDDELL, R.W. - Permanent stained mycological preparations obtained by slide culture. Mycologia, 42: 265-270, 1950.

13. RUBIN, H.A.; BRUCE, S.; ROSEN, T. \& McBRIDE, M.E. - Evidence for percutaneous inoculation as the mode of transmission for chromoblastomycosis. J. Amer. Acad. Derm., 25: 951-954, 1991.

14. SILVA, C.M.; DA ROCHA, R.M.; MORENO, J.S. et al. - The coconut babaçu (Orbignya phalerata martins) as a probable risk of human infection by the agent of chromoblastomycosis in the State of Maranhão, Brazil. Rev. Soc. bras. Med. trop., 28: 49-52, 1995 .

15. SILVA, J.P.; DE SOUZA, W. \& ROZENTAL, S. - Chromoblastomycosis: a retrospective study of 325 cases on Amazonic Region (Brazil). Mycopathologia (Den Haag), 143: 171-175, 1998.

16. ZEPPENFELDT, G.; RICHARD-YEGRES, N. \& YEGRES, F. - Cladosporium carrionii hongo dimórfico en cactáceas de la zona endémica para la cromomicosis en Venezuela. Rev. iberoamer. Micol., 11: 61-63, 1994.

Received: 02 December 2003

Accepted: 03 February 2004 